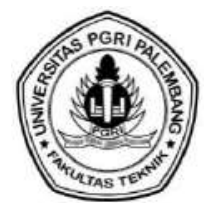

\title{
PREDIKSI DAN ANALISIS BERAT GEDUNG DENGAN STRUCTURAL ANALYSIS PROGRAM 2000 (SAP 2000) DAN METODE ARTIFICIAL NEURAL NETWORK
}

\author{
Fadhila Firdausa $^{1 *}$, Arfan Hasan ${ }^{2}$ \\ Jurusan Teknik Sipil, Politeknik Negeri Sriwijaya \\ *Corresponding Author,Email: fadhilafirdausa@polsri.ac.id
}

\begin{abstract}
ABSTRAK
Kemajuan pengembangan teknologi telah mengalami banyak kemajuan, salah satunya terus berkembangnya software. Salah satu contoh perkembangan software saat ini adalah software dibidang struktur dan matlab. Software struktur yang dimaksud salah satunya adalah aplikasi Structural Analysis Program (SAP 2000). Program SAP 2000 ini sudah banyak berkembang dan sering digunakan sebagai alat bantu untuk penelitian. Selain program SAP 2000 program matlab juga sering digunakan dalam penelitian bahkan sebagai alat pembelajaran. Program matlab saat ini juga mampu digunakan untuk memprediksi dan menganalisis suatu masalah yang ada. Banyak penelitian yang telah dilakukan dengan penggunaan software matlab. Gedung merupakan salah satu konstruksi bangunan yang sering digunakan dalam penelitian. Banyak hal yang dapat diteliti dari gedung. Salah satunya adalah berat gedung itu sendiri. Berat gedung ini dapat dilihat dari hasil running program SAP 2000. Program SAP 2000 sendiri mampu menganalisis dan mendesain konstruksi bangunan. Berat gedung ini nantinya dapat digunakan untuk memudahkan rencana anggaran biaya yang akan digunakan. ANN sendiri juga telah sering digunakan untuk memprediksi berbagai macam hal. Karena hal menarik itulah dan karena penggunaaan ANN dalam penelitian prediksi telah sering. Hasil eror terkecil berhenti pada trial epoch 200. Trial epoch 200 tersebut menghasilkan eror terbesar 38\% dan eror terkecil 0,02\%. Hasil penelitian ini, didapatkan ANN cukup mampu menghitung prediksi berat gedung yang divariasi panjang dan tinggi.
\end{abstract}

Kata Kunci : Analisis, Artificial Neural Network (ANN), Berat Gedung, Prediksi

\section{PENDAHULUAN}

Kemajuan pengembangan teknologi telah mengalami banyak kemajuan, salah satunya terus berkembangnya software. Salah satu contoh perkembangan software saat ini adalah software dibidang struktur dan matlab.Software struktur yang dimaksud salah satunya adalah aplikasi Structural Analysis Program (SAP 2000). Program SAP 2000 ini sudah banyak berkembang dan sering digunakan sebagai alat bantu untuk penelitian. Selain program SAP 2000 program matlab juga sering digunakan dalam penelitian bahkan sebagai alat pembelajaran. Program matlab saat ini juga mampu digunakan untuk memprediksi dan menganalisis suatu masalah yang ada. Banyak penelitian yang telah dilakukan dengan penggunaan software matlab. Salah satunya penelitian menggunakan Analisis Neural Network (ANN). ANN pernah digunakan dalam penelitian untuk memprediksi nilai rating faktor jembatan dan dimensi jembatan.

Gedung merupakan salah satu konstruksi bangunan yang sering digunakan dalam penelitian. Banyak hal yang dapat diteliti dari gedung. Salah satunya adalah berat gedung itu sendiri. Berat gedung ini dapat dilihat dari hasil running program SAP 2000. Program SAP 2000 sendiri mampu menganalisis dan mendesain konstruksi bangunan. Berat gedung ini nantinya dapat digunakan untuk memudahkan rencana anggaran biaya yang 
akan digunakan. ANN sendiri juga telah sering digunakan untuk memprediksi berbagai macam hal. Karena hal menarik itulah dan karena penggunaaan ANN dalam penelitian prediksi telah sering dilakukan, ANN akan digunakan sebagai metode penelitian ini untuk mengetahui hasil prediksi berat gedung yang telah didesain pada SAP 2000.

Dalam penelitian nantinya akan dilakukan variasi - variasi terhadap panjang dan tinggi gedung. Sedangkan ukuran lebar tidak dilakukan variasi dan beban yang diberikan hanya beban mati dan hidup saja, dikarenakan penelitian ini masih dalam tahap penelitian awal. Diharapkan setelah penelitian ini selesai dapat dilakukan penelitian baru dengan beban - beban lengkap yang sesuai dengan standar pembebanan untuk mendesain gedung, sehingga kedepan prediksi ANN ini dapat digunakan sebagai perkiraan awal berat gedung dan dapat dijadikan perkiraan untuk menentukan rencana anggaran biaya mendesain gedung.

\section{Tujuan Penelitian}

1. Dapat menghitung berat gedung yang divariasi terhadap panjang dan tinggi dengan aplikasi SAP 2000.

2. Dapat membuktikan kemampuan Analisis Artificial Neural Network (ANN) dengan metode Back Propagation dalam menganalisis jumlah berat gedung yang telah divariasi.

3. Dapat menghitung eror yang dihasilkan melalui analisis ANN dengan pendataan dari hasil running SAP 2000.

\section{TINJAUAN PUSTAKA}

\section{Prediksi Nilai Rating Factor Jembatan Komposit Baja-Beton Dengan Menggunakan Artificial Neural Network.}

Penelitian ini dilakukan oleh Rahmadi (2014) mengenai Prediksi Nilai Rating Factor Jembatan Komposit Baja-Beton Menggunakan Artificial Neural Network. Jembatan komposit pada umumnya menggunakan struktur komposit dari baja struktural dan beton bertulang. Struktur komposit balok baja dan pelat beton adalah suatu usaha dalam mendapatkan suatu konstruksi yang baik dan efisien. Kelebihan pada sistem komposit ini antara lain penghematan berat baja, penampang balok baja dapat lebih kecil, kekakuan lantai meningkat dan panjang bentang untuk batang tertentu dapat lebih besar. Jembatan komposit sebaiknya selalu dievaluasi agar kondisi terakhir dari jembatan dapat diketahui masih layak atau tidak untuk mendukung beban. Salah satu cara untuk mengevaluasi jembatan komposit adalah dengan menggunakan rating factor. Saat ini metode analisis yang digunakan untuk menghitung rating factor cukup panjang dan lama, sehingga diperlukan suatu metode baru untuk memprediksi rating factor dengan cepat.

Pada penelitian ini digunakan metode Artificial Neural Network untuk dapat membantu proses perhitungan nilai rating factor sebuah jembatan yang penampangnya tipikal sehingga waktu dan tenaga yang diperlukan lebih efektif dan efisien. Penampang jembatan yang digunakan sebagai bahan penelitian ialah Jembatan Merangin yang terletak di Provinsi Jambi. Jembatan Merangin merupakan jembatan dengan sistem gelagar komposit baja-beton. Perhitungan analisis rating factor berpedoman pada Pedoman Penentuan Nilai Sisa Kapasitas Jembatan dari Dirjen Bina Marga dengan melakukan analisis terhadap kondisi harian (operating) dan kondisi khusus (inventory). 
Penelitian menghasilkan empat persamaan empiris yang didapatkan dari Artificial Neural Network. Persamaan empiris ini digunakan untuk memprediksi nilai operating rating factor kuat geser, operating rating factor kuat lentur, inventory rating factor kuat geser dan inventory rating factor kuat lentur berdasarkan kedalaman penetrasi korosi, bentang jembatan, kuat tekan pelat beton dan tegangan leleh gelagar baja. Hasil penelitian menunjukkan bahwa kesimpulan akhir hasil prediksi persamaan empiris hasil pemodelan ANN mengenai masih aman atau tidaknya jembatan untuk menahan beban yang bekerja tetap sama dengan hasil hitungan secara teoritis. Oleh karena itu, persamaan empiris yang dihasilkan dapat digunakan untuk memprediksi secara cepat nilai rating factor jembatan.

\section{Optimasi Dimensi Profil Batang Bangunan Atas Jembatan Rangka Baja Tipe Warren Tertutup Dengan Metode Artificial Neural Network}

Penelitian ini dilakukan oleh Firdausa (2015) mengenai Optimasi Dimensi Profil Batang Bangunan Atas Jembatan Rangka Baja Tipe Warren Tertutup Dengan Metode Artificial Neural Network. Optimasi dimensi perlu dilakukan untuk mengoptimasi dimensi profil yang paling optimum berdasarkan variasi bentang jembatan, tinggi jembatan, dan kelas jalan tanpa mengabaikan peraturan yang berlaku. Jembatan tipe warren merupakan tipe jembatan dengan bentuk segitiga sama kaki atau segitiga sama sisi tanpa menggunakan elemen vertikal ditengah segitiga (Pedoman Pemeriksaan Jembatan Rangka Baja, Bina Marga). Artificial Neural Network merupakan sebuah pemodelan matematis yang dapat membentuk suatu persamaan pendekatan terhadap suatu proses dari hasil kumpulan input dan output. Pada penelitian ini persamaan dibentuk dari kumpulan input berupa bentang jembatan, tinggi jembatan, dan kelas jalan. Mutu baja dan jenis profil yang digunakan yaitu ketersediaan jenis profil yang ada di Bina Marga.

Bentang jembatan divariasikan dari 40 meter hingga 60 meter dengan range variasi antar bentang 5 meter. Tinggi jembatan yang divariasikan dimulai dari ketinggian 6 meter hingga 7 meter dengan range variasi tinggi 0,1 meter. Kelas jalan yang divariasikan yaitu kelas jalan A dan B. Pemodelan pada SAP 2000 hanya dilakukan terhadap 12 model. Hasil dari gaya - gaya batang dianalisis terhadap kemampuan profil terhadap tahanan gaya tarik, tahanan gaya tekan serta penurunan tegangan akibat fatik. Analisis tahanan gaya tarik dan tekan mengacu pada RSNI T-03-2005 dan analisis penurunan fatik mengacu pada AASHTO 2012. Setelah mendapatkan dimensi yang aman dari gaya tarik, gaya tekan, dan penurunanan tegangan terhadap fatik maka didapatkan berat truss. Berat truss yang telah optimum selanjutnya digunakan sebagai output dari training Artificial Neural Network.

Hasil output berat dari ANN selanjutnya dikonversikan kedalam ukuran dimensi profil. Dari hasil dimensi profil tersebut, dihitung ulang kedalam SAP 2000 kembali. Hasil penelitian menunjukkan bahwa Artificial Neural Network mampu menganalisis berat optimum truss dengan eror output terhadap input yang dimasukkan sebesar 3,3\% dan hasil ukuran dimensi yang didapat dari ANN dinyatakan aman setelah dihitung ulang menggunakan SAP 2000. 
Optimization Parameter of Neural Network for Time Series Data to Predict The Magnitude of Periodics Earthquake (Study Case Earthquake in North Maluku)

Penelitian ini dilakukan oleh Muzakir Hi Sultan (2014). Penelitian ini mengoptimasi parameter pada data time series untuk memprediksi rata - rata kekuatan gempa perperiode. Gempa bumi merupakan suatu pergerakan tanah yang terjadi secara tiba - tiba hingga menimbulkan getaran, besarnya kekuatan gempa dapat mengakibatkan baik bencana maupun korban jiwa. Untuk mengantisipasi bencana yang akan datang maka diperlukan suatu model khususnya untuk meramalkan besarnya kekuatan gempa. Pada penelitian ini digunakan model ARIMA (Autoregresive Integrated Moving Average) dan model kombinasi Neural Network - Algoritma Genetik (NN-GA) untuk memprediksi rata - rata kekuatan gempa bumi setiap bulan khususnya yang terjadi di Maluku Utara.

Data yang digunakan adalah data kekuatan gempa berdasarkan skala richter yang diperoleh dari Badan Meteorologi, Klimatologi dan Geofisika (BMKG) kota Ternate. Sebagai input pada model ARIMA dan NN-GA digunakan rata-rata kekuatan gempa bumi 36 bulan dan rata-rata kekuatan gempa 36 bulan berikutnya digunakan sebagai target untuk prediksi. Untuk meng-update parameter (bobot) dari Neural Network digunakan metode Gradient Descent dan untuk mendapatkan parameter yang lebih optimal pada layer Output, maka di diterapkan Algoritma Genetik. Hasil peramalan dari kedua model kemudian dibandingkan dari hasil peramalan dengan model ARIMA diperoleh MSE sebesar 1.0125 sedangkan pada model $N N-G A$ diperoleh $M S E$ sebesar 0.9196. Nilai tersebut, menunjukkan bahwa model $N N-G A$ lebih baik dari model ARIMA untuk peramalan rata-rata kekuatan gempa bumi beberapa bulan ke depan.

\section{METODE PENELITIAN}

\section{Materi Penelitian}

Materi pokok dalam penelitian ini adalah melakukan prediksi perhitungan berat gedung dengan variasi terhadap panjang dan tinggi gedung yang didapatkan dari hasil SAP 2000. Pemodelan yang digunakan dalam penelitian ini menggunakan Artificial Neural Network (ANN) dengan metode Backpropagation dengan bantuan software Matlab. Peralatan yang digunakan dalam penelitian ini adalah seperangkat komputer yang telah terinstal program Matlab.

\section{Peralatan Penelitian}

Peralatan yang digunakan dalam penelitian ini adalah seperangkat komputer yang telah terinstal program Matlab.

Langkah-langkah penelitian adalah sebagai berikut:

1. Mendesain gedung dengan berbagai macam variasi yang dilalukan terhadap panjang dan tinggi gedung dengan SAP 2000

2. Mengumpulkan data berat gedung yang telah dianalisis dengan program SAP 2000

3. Membuat pemodelan di Matlab dengan metode back propagation, yang mana di dalam pemodelan Matlab itu sendiri terdapat bahasa perintah pemograman atau koding yang menyatakan untuk membuat suatu jaringan syaraf.

4. Pemodelan di Matlab yang dinputkan yaitu panjang, tinggi, dan berat yang telah dikumpulkan dari hasil SAP 2000. 
5. Training pemodelan di ANN dilakukan dengan output yang dihasilkan adalah berat gedung.

6. Dari hasil berat gedung dengan ANN dihitung erornya dengan data berat gedung yang telah didapat dari SAP 2000.

\section{HASIL DAN PEMBAHASAN}

\section{Pemodelan Gedung dengan SAP 2000}

Dalam penelitian ini dilakukan dengan langkah pertama membuat pemodelan dengan SAP 2000. Dalam hal ini pemodelan gedung divariasikan terhadap panjang dan tinggi gedung. Untuk lebar gedung tidak dilakukan variasi. Untuk pembebanan gedung digunakan beban merata sebesar $100 \mathrm{~kg}$, dikarenakan ini merupakan penelitian awal maka beban hanya digunakan beban merata saja.Untuk penelitian kedepan diharapkan beban yang digunakan beban untuk mendesain gedung menurut Standar Nasional Indonesia.

Tabel 1. Variasi Desain Gedung

\begin{tabular}{|c|c|c|c|}
\hline No. & $\begin{array}{c}\text { Panjang } \\
\text { (meter) }\end{array}$ & $\begin{array}{c}\text { Lebar } \\
\text { (meter) }\end{array}$ & $\begin{array}{c}\text { Tinggi } \\
\text { (meter) }\end{array}$ \\
\hline 1. & 8 & 8 & 8 \\
\hline 2. & 12 & 8 & 8 \\
\hline 3 & 16 & 8 & 8 \\
\hline 4. & 8 & 8 & 12 \\
\hline 5. & 12 & 8 & 12 \\
\hline 6. & 16 & 8 & 12 \\
\hline
\end{tabular}

Adapun untuk ukuran balok digunakan balok beton ukuran 30 × $40 \mathrm{~cm}$ dan ukuran kolom 40 x $40 \mathrm{~cm}$, ketebalan pelat lantai 0,2 meter, dan kuat tekan beton $25 \mathrm{Mpa}$

\section{Hasil Analisis SAP 2000}

Dari hasil running SAP 2000 maka dapat direkapitulasi nilainya berdasarkan tabel berikut :

Tabel 2. Hasil Berat Gedung SAP 2000

\begin{tabular}{|c|c|c|c|c|}
\hline No. & $\begin{array}{c}\text { Panjang } \\
(\text { meter })\end{array}$ & $\begin{array}{c}\text { Lebar } \\
(\text { meter })\end{array}$ & $\begin{array}{c}\text { Tinggi } \\
(\text { meter })\end{array}$ & $\begin{array}{c}\text { Berat } \\
\text { Gedung } \\
\text { (Ton) }\end{array}$ \\
\hline 1. & 8 & 8 & 8 & 132,12 \\
\hline 2. & 12 & 8 & 8 & 161,52 \\
\hline 3 & 16 & 8 & 8 & 223,97 \\
\hline 4. & 8 & 8 & 12 & 178,55 \\
\hline 5. & 12 & 8 & 12 & 257,26 \\
\hline 6. & 16 & 8 & 12 & 335,96 \\
\hline
\end{tabular}

\section{Simulasi Artificial Neural Network Prediksi Berat Gedung}

Simulasi Artificial Neural Network dilakukan untuk mendapatkan berat gedung yang telah didapatkan dari SAP 2000. Persamaan umum ANN adalah sebagai berikut : 


$$
T_{k}><Y_{k}=\left(b_{2 k}+\left(\Sigma W_{j k} \cdot f\left(b_{1 j}+\Sigma V_{i j} \cdot X_{i}\right)\right)\right)
$$

dengan:

$T_{k} \quad=$ Target output yang dipasang

$Y_{k} \quad=$ Prediksi output

$b_{2 k} \quad=$ Bobot bias lapisan

$W_{j k} \quad=$ Bobot lapisan

$b_{i j} \quad=$ Bobot bias input

$V_{i j} \quad=$ Bobot input

$X_{i} \quad=$ Parameter input

$x_{1} \quad=$ Panjang

$\mathrm{x}_{2} \quad=$ Tinggi

Jumlah Input Layer yang digunakan $(X)=2$

Jumlah Hidden Layer yang digunakan $(Z)=2$

Jumlah Output Layer yang digunakan $(Y)=1$

Batas iterasi $($ epoch $)=10000$

Target error maksimum $\left(E_{\max }\right)=1 \mathrm{e}-11$

Selanjutnya, setelah mengumpulkan data berat gedung dari hasil SAP 2000 maka dilakukan pembuatan pemodelan di Matlab dengan metode back propagation, yang mana di dalam pemodelan Matlab itu sendiri terdapat bahasa perintah pemograman atau koding yang menyatakan untuk membuat suatu jaringan syaraf. Pemodelan di Matlab yang dinputkan yaitu bulan, tahun, dan jumlah penumpang yang telah dikumpulkan. Namun, berat gedung yang dimasukkan ke dalam input tidak semua, hal ini dimaksudkan agar ANN dapat memprediksi berat gedung yang tidak diinputkan.

Berat gedung yang dijadikan input hanya berat gedung pada model pertama, model ketiga, model keenam. Bahasa perintah yang digunakan untuk melakukan simulasi training di Matlab adalah sebagai berikut :

clear;

$\%$ Data input \& target

Data $=[\ldots$

$8 \quad 8 \quad 132,12$

168223,97

1612 335,96];

$\mathrm{P}=\operatorname{Data}(:, 1: 2)^{\prime}$

$\mathrm{T}=\operatorname{Data}(:, 3)^{\prime}$;

$\%$ Membangun jaringan syaraf feedforward

net $=\operatorname{newff}(\operatorname{minmax}(\mathrm{P}),[21],\{$ 'logsig' 'purelin' $\}$, 'trainscg');

$\%$ Set max epoch, goal, learning rate, momentum, show step

net.trainParam. epochs $=200$;

net.trainParam.goal $=1 \mathrm{e}-11$;

net.trainParam. $1 \mathrm{r}=0.1$; 
net.trainParam. show $=100$;

net.trainParam.min_grad $=1 \mathrm{e}-10$;

$\%$ Melakukan pembelajaran

net $=\operatorname{train}($ net $, P, T)$;

$\%$ Melihat bobot-bobot awal input, lapisan dan bias

BobotAwal_Input $=$ net.IW $\{1,1\}$;

BobotAwal_Bias_Input $=$ net.b $\{1,1\}$;

BobotAwal_Lapisan = net.LW $\{2,1\}$;

BobotAwal_Bias_Lapisan $=$ net.b $\{2,1\}$;

$\%$ Melakukan simulasi

$\mathrm{y}=\operatorname{sim}($ net, $\mathrm{P})$;

Trial ANN dimulai dari epoch coba - coba yaitu 100 sampai mendekati trial epoch yang nilai erornya paling kecil, dan trial epoch berhenti dinilai 200 karena pada trial epoch 300 eror mengalami kenaikan.

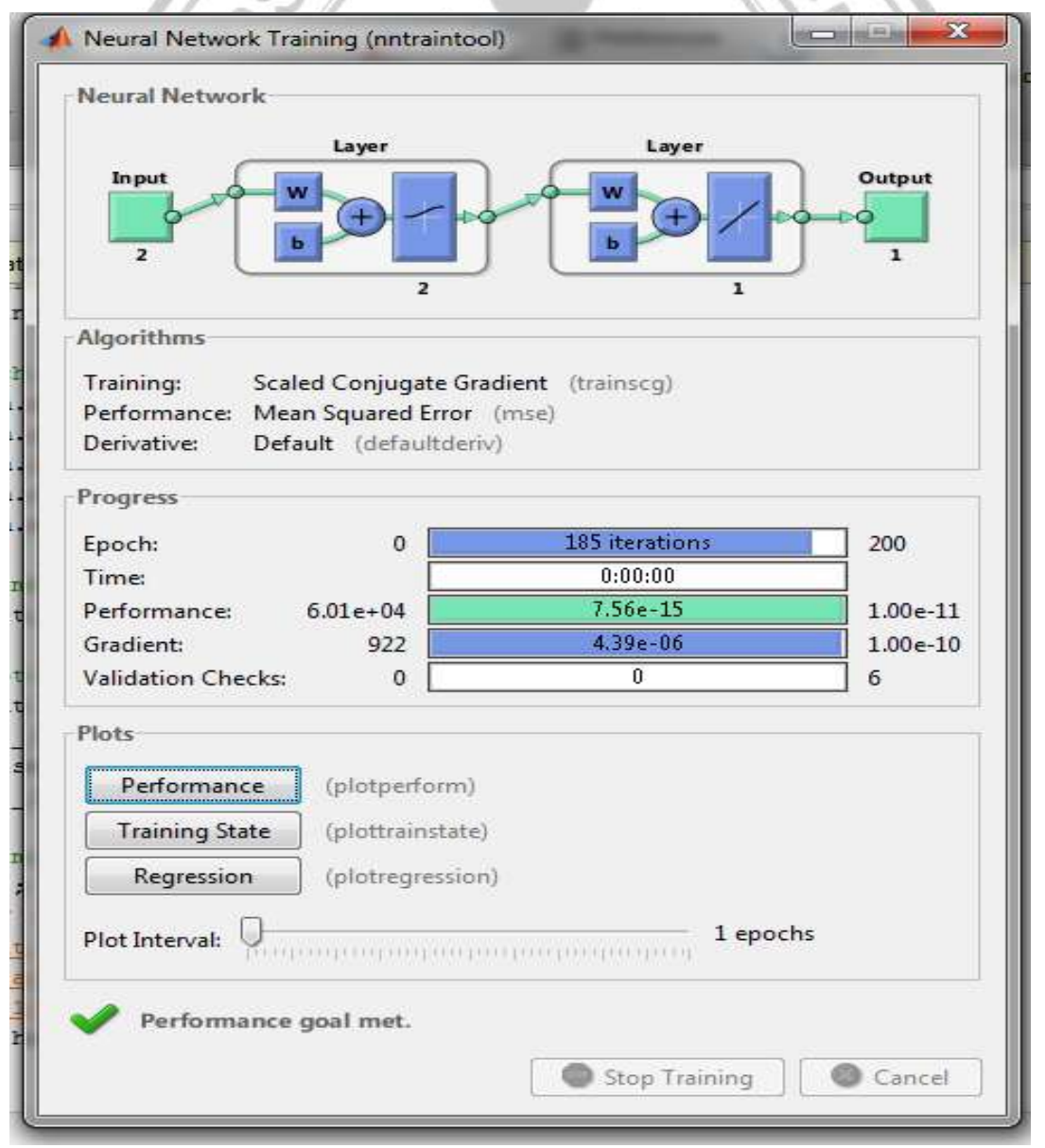

Gambar 1. Proses Training ANN 


\section{Hasil Training ANN}

Trial Epoch 200

Hasil Olah ANN

$\begin{array}{lcl}\text { V }[1,1] & -4,1531862 & \text { BOBOT INPUT } \\ \text { V }[1,2] & 6,9903443 & \text { BOBOT INPUT } \\ \text { V }[2,1] & 5,8198955 & \text { BOBOT INPUT } \\ \text { V }[2,2] & -5,129005 & \text { BOBOT INPUT } \\ \text { b }[1,1] & -1,5307633 & \text { BOBOT BIAS INPUT } \\ \text { b }[1,2] & -18,176416 & \text { BOBOT BIAS INPUT } \\ \text { W }[1,1] & 112,00097 & \text { BOBOT LAPISAN } \\ \text { W }[1,2] & 203,00097 & \text { BOBOT LAPISAN } \\ \text { b }[2,1] & 19,998376 & \text { BOBOT BIAS LAPISAN }\end{array}$

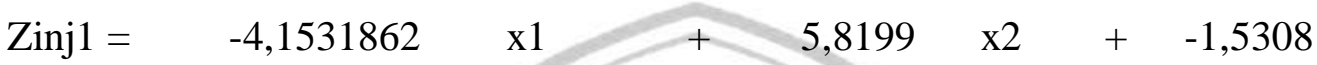

$$
\begin{aligned}
& \text { Zinj2 }=6,99 \mathrm{E}+00 \quad \mathrm{x} 1 \quad \mathrm{P}+\mathrm{P} / \mathrm{x}, 129+-18,176 \\
& \mathrm{Z} 1=1 /\left(1+\exp ^{\wedge}(-\mathrm{Zinj} 1)\right. \\
& \mathrm{Z} 2=1 /\left(1+\exp ^{\wedge}(-\mathrm{Zinj} 2)\right. \\
& \mathrm{Y}=19,998376+\mathrm{Z} 1-112,001+\mathrm{Z} 2 \quad 203,001
\end{aligned}
$$

Tabel 3. Perhitungan Eror Berat Gedung SAP 2000 dengan Berat Gedung Hasil Prediksi Artificial Neural Network (ANN)

\begin{tabular}{|c|c|c|c|c|c|c|c|c|c|}
\hline No & $\begin{array}{c}\mathrm{x} 1 \\
\text { (panjang) }\end{array}$ & $\begin{array}{c}\mathrm{x} 2 \\
\text { (tinggi) }\end{array}$ & Zinj1 & Zinj2 & Z1 & Z2 & $\begin{array}{c}\text { Y } \\
\text { (ANN) }\end{array}$ & $\begin{array}{c}\mathrm{y} \\
\text { (data) }\end{array}$ & Eror \\
\hline 1 & 8 & 8 & 11,803 & $-3,2857$ & 1 & 0,04 & 139,32 & 132,11 & 5,45738 \\
\hline 2 & 12 & 8 & $-4,8098$ & 24,6757 & 0,01 & 1 & 223,905 & 161,52 & 38,6235 \\
\hline 3 & 12 & 8 & $-4,8098$ & 24,6757 & 0,01 & 1 & 223,905 & 223,97 & 0,02916 \\
\hline 4 & 8 & 12 & 35,082 & $-23,802$ & 1 & 0 & 131,999 & 178,55 & 26,0715 \\
\hline 5 & 12 & 12 & 18,47 & 4,15966 & 1 & 0,98 & 331,88 & 257,26 & 29,0055 \\
\hline 6 & 16 & 12 & 1,857 & 32,121 & 0,86 & 1 & 319,874 & 335,96 & 4,78798 \\
\hline
\end{tabular}


Dari hasil tabel diatas maka dapat dibuat grafik sebagai berikut :

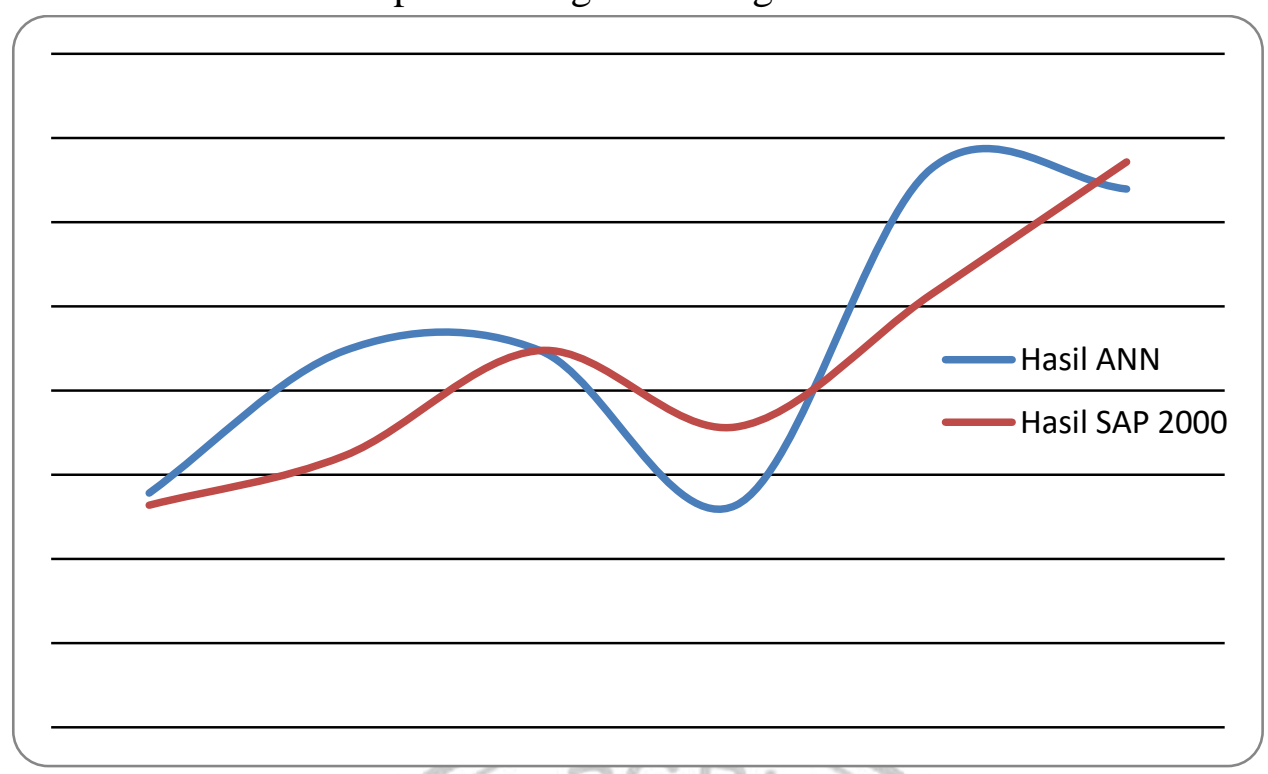

Gambar 2. Grafik Nilai Eror Prediksi ANN

\section{KESIMPULAN}

1. Eror yang dihasilkan oleh ANN tertinggi sebesar $38 \%$ dan terkecil $0,02 \%$.

2. Trial epoch berhenti pada angka 200 yang sebelumnya telah dilakukan training mulai dari trial epoch 100 .

3. Trial epoch 300 mengalami kenaikan nilai eror, sehingga trial akhir berhenti pada trial epoch 200.

4. ANN dinilai cukup mampu berat gedung dengan variasi panjang dari 8 meter sampai 16 meter dan variasi tinggi 8 meter sampai 12 meter.

\section{DAFTAR PUSTAKA}

Adeli, H., 2001, Neural Network in Civil Engineering : 1989 - 2000, Computer Aided Civil and Infrastructure Engineering, hal. 126-142. USA

Agrawal, V., Nagar, R., dan Sancheti, G., 2011, Application of Artificial Neural Network in Conceptual Design of Communication Towers, International Conference on Electrical, Electronics and Civil Engineering (ICEECCE'2011), Pattaya

Firdausa, F., 2015, Optimasi Dimensi Profil Batang Bangunan Atas Jembatan Rangka Baja Tipe Warren Tertutup Dengan Metode Artificial Neural Network, Naskah Tesis: UGM, Yogyakarta

Kusumadewi, S., 2004, Membangun Jaringan Saraf Tiruan Menggunakan MATLAB \& Excel Link, Penerbit Graha Ilmu, Yogyakarta

Moghadas, R., Choong, K.K., dan Mohd, S.B., 2012, Prediction of Optimal Design and Deflection of Space Structures Using Neural Networks, Hindawi Publishing Corporation, vol. 2012, doi:10.1155/2012/712974

Rahmadi N.H., 2014, Prediksi Nilai Rating Faktor Jembatan Komposit Baja-Beton Dengan Menggunakan Artificial Neural Network, Nakah Tesis: UGM, Yogyakarta 
Siang, J.J., 2004, Jaringan Saraf Tiruan \& Pemrogramannya Menggunakan MATLAB, Penerbit ANDI, Yogyakarta

Suhairil, M., 2012, Frame Optimization using Neural Network, International Journal on Advanced Science Engineering Information Technology, Vol. 2 No.1, Malaysia

Sultan, M.H., Optimization Parameter of Neural Network for Time Series Data to Predict The Magnitude of Periodics Earthquake (Study Case Earthquake in North Maluku), Magister Mathematics University Brawijaya, Malang

Yudistira. A.T., 2014, Prediksi Penurunan Kapasitas Struktur Atas Jembatan Rangka Baja Menggunakan Metode Artificial Neural Network, Naskah Tesis: UGM, Yogyakarta

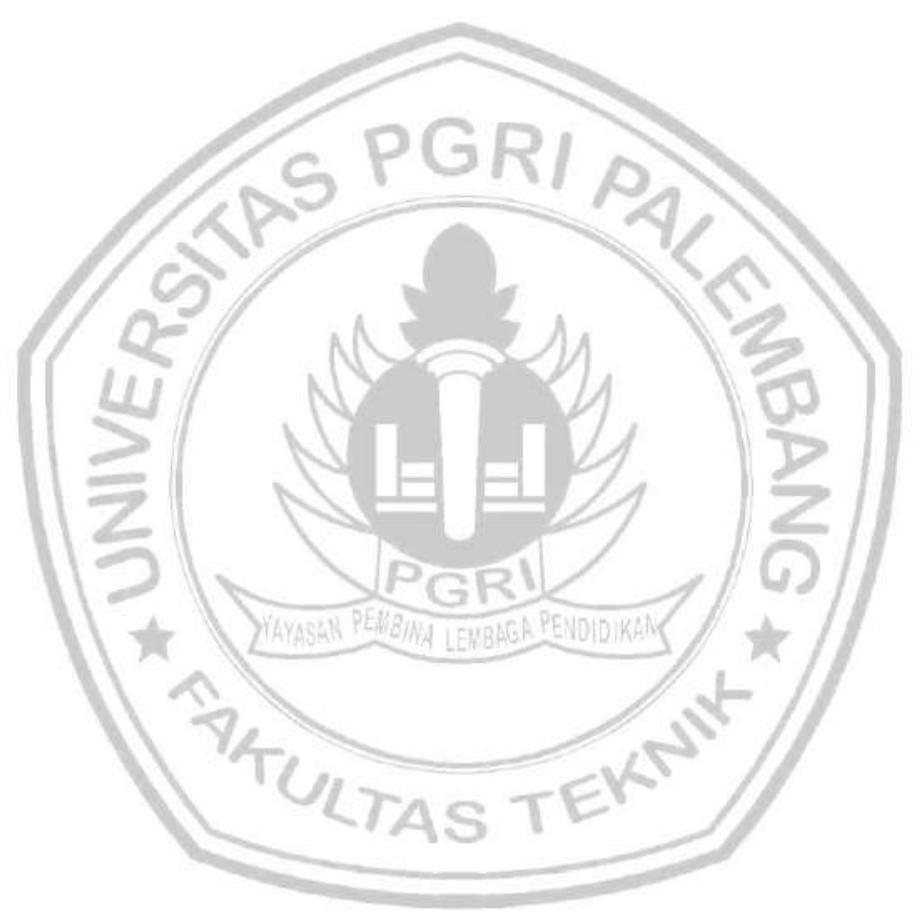

